\title{
Morphological and phytochemical characterization of susceptible and resistant sengon (Falcataria moluccana) tree to gall rust disease
}

\author{
DEWI RAHMAWATI ${ }^{1}$, NURUL KHUMAIDA ${ }^{2}$, ULFAH J. SIREGAR ${ }^{1,3, \boldsymbol{v}}$ \\ ${ }^{1}$ Department of Research, Southeast Asian Regional Centre for Tropical Biology (SEAMEO BIOTROP). Jl. Raya Tajur Km 6, Bogor 16134, West Java, \\ Indonesia. Tel.: +62-251-8323848; Fax.: +62-251-8326851, `email: siregaruj@gmail.com \\ ${ }^{2}$ Department of Agronomy, Faculty of Agriculture, Institut Pertanian Bogor. Jl. Raya Dramaga, Bogor 16680, West Java, Indonesia \\ ${ }^{3}$ Department of Silviculture, Faculty of Forestry, Institut Pertanian Bogor. Jl. Raya Dramaga, Bogor 16680, West Java, Indonesia
}

Manuscript received: 5 January 2019. Revision accepted: 28 February 2019.

\begin{abstract}
Rahmawati D, Khumaida N, Siregar UJ. 2019.Morphological and phytochemical characterization of susceptible and resistant sengon (Falcataria moluccana) tree to gall rust disease. Biodiversitas 20: 907-913. Gall rust disease has severely attacked sengon tree (Falcataria moluccana Miq. Barneby \& J.W. Grimes)) and it rapidly spread in tree plantations, causing decrease in wood productivity. Although sengon is widely cultivated in several areas in Indonesia, there are limited studies on secondary metabolite composition of its wood. This research aimed to study differences on morphology, wood anatomy and secondary metabolites content of resistant and susceptible sengon tree trunk to gall rust disease. Both resistant and susceptible tree samples to gall rust were selected from the same plantation plots to minimize environmental effects. Structure of wood samples was observed using Scanning Electron Microscope (SEM) JSM-5310LV. Seven types of secondary metabolites, i.e., alkaloids, flavonoids, saponins, phenolic hydroquinones, tannins, triterpenoids, and steroids were qualitatively analyzed from powdered wood samples. Based on field observations, the gall rust fungi changed the color, texture, pores of the tree surface and decreased wood density. In microscopic observations, sengon trunk, which is resistant to gall rust disease, showed organized and regularly structured wood anatomy and did not show hyphae of the infecting fungi inside the wood. The fungi damaged susceptible sengon trunk as indicated by the dispersed and irregular structure of wood tissue, while the presence of fungal hyphae among wood cells was detected. Phytochemical analyses indicated that trunk of sengon containing flavonoids, saponins, phenolic hydroquinones, tannins, triterpenoids, and steroids, except alkaloids. Sengon trunk, which is resistant to gall rust disease, had stronger reactions of flavonoids, saponins, triterpenoids, and steroids compared to that susceptible one.
\end{abstract}

Keywords: Falcataria moluccana, galls rust disease, phytochemical, resistant, Scanning Electron Microscope

\section{INTRODUCTION}

Sengon (Falcataria moluccana Miq.) Barneby \& JW Grimes is widely cultivated as community forest plantation in Java Island, Indonesia, and it is important raw material for wood industries such as furniture, housing construction, packing box, pulp, paper and other purposes. As the mix community plantation becoming monoculture system, many pests and diseases attack the plantations (Darwiati and Anggraeni 2018). The stem borer pest (Xystrocera festiva) usually starts attacking sengon trees aged 3 years old and could potentially destroy a plantation when unattended. Recently, gall rust disease has also become a serious problem in sengon plantations because it could also damage sengon wood and spreads quickly. The disease is caused by infection of the fungi Uromycladium falcatarium (Sacc.) McAlpine) (Doungsa-ard et al. 2015). Unlike the stem borer pest, the fungi infection usually starts at early age of sengon plants and can cause the death of sengon tree and seedlings as well (Rahayu et al. 2010). Both the stem borer pest and the gall rust disease could infect a sengon plantation at the same time, which sharply reduce wood production. Both the pest and disease are not only able to damage the wood quality, they can cause tree death, thereby reducing economic profit considerably. The decline in sengon wood production can have an impact on the timber industry based on sengon. Disease attacks caused production losses to reach $73.5 \%$ (Wiryadiputra 2007).

The first symptom of gall rust disease is the occurrence of long and round until round to oval spots on the surface of sengon trunk. The symptom is then followed by a swelling of the trunk tissue and showed reddish brown spots on the trunk, which indicates anatomical structure change. Any infections on tree trunk will significantly disturb wood tissue development, resulting in low strength quality of wood (Muin et al. 2000). The quality of wood eventually can be damaged by pathogens. Defianti et al. (2015) reported similar cases on Langsat trees (Lansium domesticum Corr.) and stated that parenchyma tissue thickness, cortex size and shape were altered by canker. This stem canker is a plants disease caused by infection of Phytophthora palmivora fungi on stems, branches, and twigs of the plants. Although pathogens infect the plant cells mechanically, the pathogen activity in the tissues is more chemical in nature. Pathogens would take compounds from plants; however, pathogens first must be able to pass through physical barriers such as cuticles and cell walls. Pathogens infect plants, utilize nutrient compounds and survive from host defense systems.

In general, wood consists of 3 major constituents, i.e. cellulose, hemicellulose and lignin, which influence wood physical and chemical characteristics. Changes in dimension and environment, as well as ecosystem degradation, could cause decrease in wood quality (Deka and Saikia 2000). 
Secondary metabolites are chemical compounds playing certain role in the plant. Secondary metabolite in wood is often called extractives. Some wood compounds are composed of extractive substance and each compound has its specific role, such as in susceptibility against fungi and insect attacks, producing the wood smell, taste and color, and molecular signaling. As confirmed by Verpoorte and Alfermann (2000), among functions of secondary metabolite is to protect the plant from unfavorable environmental conditions. Identification of secondary metabolite contents is an important initial step to investigate bioactive compound having a role as the defense against diseases. Bioactive compound such as flavonoids is phenolic compounds found in all plant tissues, especially in vacuoles and are present in a mixture of single components and polymers on bark and heartwood. These compounds had the function of inducing host resistance responses.

Phytochemical screening is a method to determine secondary metabolites in plants. Characterization of secondary metabolite compounds is usually first attempt to investigate plant resistance against some diseases, which consist of alkaloids, triterpenoids, steroids, tannins, flavonoids and saponins tests (Harborne 1984). Study on secondary metabolite compounds of sengon leaves has been carried out by Eleanore (2013) which showed that sengon leaves contain alkaloids, saponins, flavonoids, tannins, phenolics, steroids and triterpenoids. The objective of this study was to investigate differences in morphological structures and secondary metabolites between resistant and susceptible sengon trunks against gall rust disease. The following hypothesis was tested: there are differences in the morphological characters (phenotypes) and the amount of secondary metabolite contents in sengon wood which are resistant and susceptible to gall rust.

\section{MATERIALS AND METHODS}

Sengon trees used in this research came from the same seed sources and belong to PT Bojong Asih Sukabumi forest plantations, a local company located in Sukabumi, West Java, Indonesia. Resistant wood is a healthy tree that is not infected by gall rust while susceptible wood is severely attacked by gall rust. Individuals resistant and susceptible to gall rust were sampled from the same plantation plots to eliminate differences in microclimate condition. The sengon trees used as samples for gall rust observations aged 3 years old. Observations on gall rust infection progression included the part of sengon twigs and trunks that were attacked and not attacked by gall rust. Before taking wood sample for anatomical and biochemical analysis, it was necessary to confirm whether the tumor has formed in the plant tissues by the gall rust fungi.

\section{Morphological observation method}

Morphological observations were carried out visually, followed by documentation for sengon tree samples that were attacked and not attacked by gall rust disease. The observed characters included the color, texture, and pores of the tumor, trunk surface, and wood solidity.

\section{Wood anatomy analysis using Scanning Electron Microscope (SEM)}

Wood samples were taken using machete, and then immersed in $85 \%$ alcohol during transportation to the laboratory, prior to sequential treatments for Scanning Electron Microscope (SEM) readings. Samples were immersed in $85 \%$ alcohol followed by several treatments according to the manual published by the Research Centre of Zoology of Indonesia Institute of Sciences (LIPI) Indonesia: (i) Pre-fixation by immersion in $2.5 \%$ glutaraldehyde solution for several hours up to 2 days at $4^{\circ} \mathrm{C}$. (ii) Fixation by immersion in $2 \%$ tannic acid at $4^{\circ} \mathrm{C}$ for 6 hours, and then rinsed 4 times using cacodylate buffer. Each rinsing was carried out for 5 minutes at $4{ }^{\circ} \mathrm{C}$. (iii) Dehydration by immersion the samples in $50 \%$ alcohol serial solution 4 times, each for 5 minutes at $4^{\circ} \mathrm{C}$. Samples were then immersed in $70 \%$ alcohol for 20 minutes at $4^{\circ} \mathrm{C}$, followed by $80 \%$ alcohol for 20 minutes at $4^{\circ} \mathrm{C}$ and subsequently in $95 \%$ alcohol for 20 minutes at room temperature. The last dehydration step was double immersion in absolute alcohol for 10 minutes at room temperature. (iv) Drying by immersion in the tert-buthanol solution for 10 minutes and repeated 2 times. Subsequently, samples were frozen in the freezer at $-20^{\circ} \mathrm{C}$ for 1 day. Samples were then vacuum dried for 20 minutes. (v) Coating, of which samples were attached to specimen stub using carbon glue followed by gold coating for 5 minutes. After gold coating treatment, the samples were ready for observation under Scanning Electron Microscope using SEM type JSM-5310LV.

\section{Secondary metabolite analysis using Harborne method (1984)}

Wood samples were taken from the same individuals used for other observations $(\mathrm{n}=\mathrm{X}$ resistant and $\mathrm{Y}$ susceptible individuals) as for SEM observation using machete and sundried. The sengon tree sample was chosen based on severity infection on wood, of which severely infected trees were compared to clearly not-infected with gall rust.

There were each 25 sengon accessions that were resistant and susceptible to gall rust from Sukabumi, and they were collected and tested phytochemically. Subsequently, the samples were finely ground into powder. As much as $500 \mathrm{mg}$ of powdered sample was used for each test conducted in this analysis.

Phytochemical screening is very easy, yet useful as an initial analytical method for determining the types of secondary metabolites found in plants. The results could serve as screening derminants to differentiate plant accessions, as the rections are very specifically designed. The types of secondary metabolites related to resistance as supporting information in a phytochemical screening includes testing of alkaloids, tannins, flavonoids, saponins, triterpenoids and steroids (Harbrone 1984).

\section{Alkaloid test}

For this experiment, $500 \mathrm{mg}$ of powdered sample was diluted in $5 \mathrm{~mL}$ chloroform, and then 5 drops of $\mathrm{NH}_{4} \mathrm{OH}$ was added to obtain the base solution. The solution was shaken and filtered to obtain chloroform extract. After that, 
$2 \mathrm{~mL}$ of chloroform extract was diluted in 10 drops of $2 \mathrm{M}$ $\mathrm{H}_{2} \mathrm{SO}_{4}$ and shaken until 2 layers of solution were formed. The upper layer (acidic layer) was pipetted and three different drops of the acidic layer were put onto 3 different drop plates. The first drop was added with Meyer reagent, the second drop was added with Wagner reagent and the third drop was added with Dragendorf reagent. The sample is determined positive for alkaloids if the sample produces white sediment with Meyer reagent, or produces brown sediment with Wagner reagent or produces orange sediment with Dragendorf reagent (Harborne 1984).

\section{Flavonoid test}

For this test, $500 \mathrm{mg}$ of powdered sample was added with $10 \mathrm{~mL}$ hot water, boiled for 5 minutes and then filtered. The $5 \mathrm{~mL}$ of filtrate was diluted in $0.5 \mathrm{~g} \mathrm{Mg}$ powder, $1 \mathrm{~mL}$ concentrated $\mathrm{HCl}$ and $1 \mathrm{~mL}$ amyl alcohol. The solution was then vigorously shaken. The sample is determined positive for flavonoids if the color of the solution changes into yellow to dark red (Harborne 1984).

\section{Phenol hydroquinone test}

In this case, $10 \mathrm{~mL}$ methanol was put into $500 \mathrm{mg}$ of powdered sample and shaken. The sample was then boiled in hot water and then filtered. The filtrate was added with 3 drops of $10 \% \mathrm{NaOH}$. The sample is determined positive for phenol hydroquinones if the color of the solution changes becoming yellow to red (Harborne 1984).

\section{Tannin test}

The powdered sample of $500 \mathrm{mg}$ was added with 50 $\mathrm{mL}$ hot water, boiled for 15 minutes and then filtered. The filtrate was added with $10 \mathrm{~mL} 1 \% \mathrm{FeCl}_{3}$. The sample is determined positive for tannins if the color of the solution changes into green to black (Harborne 1984).

\section{Saponin test}

$500 \mathrm{mg}$ of powdered sample was boiled with $10 \mathrm{~mL}$ hot water for 5 minutes and then filtered. Ten milliliters filtrate was shaken in a closed test tube for 10 seconds and set aside for 10 minutes. The sample is determined positive for saponins if the stable foam is formed in the filtrate (Harborne 1984).

\section{Triterpenoid and steroid tests}

Powdered sample of $500 \mathrm{mg}$ was macerated using 25 $\mathrm{mL}$ absolute alcohol until boiling point and then filtered. The formed residue was heated until dry and added with ether and shaken. Three drops of anhydrous acetic acid and 1 drop of concentrated sulfuric acid were added to the filtrate. The solution was slowly shaken and set aside for 5 minutes. The sample was determined positive for triterpenoid if the color of the solution changes into red or purple and was determined positive for steroids if the color of the solution changes into green or blue (Harborne 1984).

\section{RESULTS AND DISCUSSION}

\section{Field observation of morphological symptoms}

Field observation on morphological symptoms of gall rust disease attacking sengon trunk detected the occurrence of the initial tumor having round shape and brownish green color, which then developed and covered with a layer of fungal spore (Figure 1.A). Anggraeni dan Lelana 2011 reported that in the field sengon trees show typical symptoms, namely hyperplasia (overgrowth) in parts of the affected plant. Symptoms of the disease begin with the presence of local swelling in the affected part of the plant (leaves, branches, and stems). Over time the swelling changes into a lump that then becomes small nodule or gall (Anggraeni 2009). The sporulation process developed subsequently and intensively as active spores having reddish brown color covering the tumor surface (Figure 1.B). As teliospores were formed, their viability would be greatly reduced (decrease by about 40\%) after being exposed to sunlight for 6 consecutive hours. During sporulation process, the infected sengon tree becomes a potential inoculum of disease-carrying fungi. Prevailing winds during sporulation process can disperse the spores from one infected tree to surrounding area, i.e. to other surrounding trees. Figure 1.C shows inactive spores after sporulation, indicated by black-colored tumor. Tumors that had been inactive and had green tissue sometimes were used by stem borer insects to lay the eggs, which then develop into larvae (Rahayu 2010).

The age of trees, altitude, topography, fog occurrence, vegetation density, pruning, thinning, seed source, relative humidity, and wind speed are known factors that influence gall rust disease development (Rahayu 2010). The most sensitive plant stage for gall rust disease infection is the stage of seedling and young age tree. Although not always, tumor occurrence in adult sengon tree is a result of prolonged gall rust fungi infection, which might happen at the seedling and young-age tree stages. A severe attack of gall rust disease is indicated by the massive occurrence of tumors all over the tree. The severe condition will cause falling of the leaves and branches, which lead to tree death. Fungi incubation period determines different stages of infection in the attacked sengon trees. Fungi U. falcatarium needs 10 hours after inoculation to form basidiospore. The basidiospore later forms a penetration peg at about 16 hours after inoculation (Rahayu et al. 2010). Based on their observation, the environment had influence on mode of pathogen dispersal. Development of gall rust disease was higher in low light intensity, high relative humidity and low temperature. There were an indication that enviromental factors espesially humidity strongly increased the disease intensity and sporulation of the fungi

Figure 2 showed several tumor shapes found in an infected individual plant. Tumors frequently occur at the trunk (Figure 1.A and 2.A); at the branches (Figure 2.B) and at the young twigs (Figure 2.C). Gall rust attack on tree trunk decreased the wood strength and inhibited tree growth (Rahayu 2010). According to Rahayu et al. (2010), the pathogen present in adult sengon trees is actually a development of gall rust fungi infection that happened at the seedling or young tree stages.

Comparison of resistant and susceptible individual trees in the field showed clear differences in several characters observed. Gall rust fungi grown on susceptible sengon tree trunk caused changes in color, texture, pores, trunk surface, and decrease wood density (Table 1). Original morpho- 
logical characters of sengon wood are white in color, soft to moderate in texture, straight to interlocked in fiber direction, simple in wood pattern and although have low wood density the wood is hard (Pandit et al. 2011). These characteristics were only found in the resistant individuals, while in the susceptible ones all characters are altered.

The wood in an attacked area has rough texture due to thickening of cell walls and less wood density. The wood tissue color changed from white to blackish brown. The color has changed due to cells damage as gall rust fungi infect the tree. Muin et al. (2000) explained that accumulation of gall rust fungi infection would cause blackish brown wood color. The wood color changed to brown because of lignin phytochemical decomposition. The extractive substance formed free radicals, which led to advance decomposition of structural carbohydrate as well as oxidation of part of phenolics (Muin et al. 2010). The softened wood solidity of sengon tree susceptible to gall rust disease indicated that there was a decrease in wood strength in the infected area. This might have been caused by the enzyme secreted by the infecting fungi hyphae, which can decompose wood constituents. Achmad et al. (2012) stated that the damping-off disease in Pinus merkusii was caused by the secretion of cellulosic and pectolytic enzymes by the pathogenic fungi.

Tumors of the gall rust disease covered the trunk of susceptible individuals, while trunk of resistant trees was free of tumors. The swelling tissues occurred on parts of the tree is a common symptom for infection by gall rust disease. The cell shape became abnormal due to the hormones produced by gall rust infecting fungi, which triggered excessive cell formation. Mycelia fungi damaged the cell wall causing periderm, xylem and phloem to lose their original shape. Gall rust is closely related to growth hormones that occur naturally in plants, such as indole-3acetic acid (IAA) and cytokinin (Anggareni 2009). Tumoric cells contain higher levels of IAA and cytokinin than ordinary cells, of which both hormones are suspected to cause symptoms of hyperplasia. A pathogen that infected the plant would proliferate in the space between plant cells, causing accelerated plant cell division, and accumulated cells that occur would enlarge the tissue abnormally. Fungi produced a hormone which triggers excessive cell formation causing abnormal shape such as the tumor (Rahayu and Lee 2008). Hormonal cell function in a plant can be disturbed by plant growth regulator by increasing or decreasing cell division and cell enlargement capabilities.

\section{Wood anatomy analysis using Scanning Electron Microscope (SEM)}

Differences and changes were observed in the resistant and susceptible woods under SEM (Figure 3). Sengon wood obtained from resistant tree to gall rust disease has organized, intact and regularly structured tissue (Figure 3.A and B). On the contrary, sengon wood obtained from susceptible tree to gall rust disease has abnormal, irregular, unorganized wood tissue of which cells position was not intact (Figure 3.C, D, E, F). Rahayu et al. (2010) reported that after the fungi penetrating cells of a seedling at young stage of sengon tree, the hyphae of the fungi developed in the epidermis, periderm, phloem, and xylem of the host tree. Subsequently, the cortex cell wall was destroyed by the mycelium of the fungi, which caused the irregular form of periderm and phloem. Inside the xylem, the infecting fungi formed intracellular haustorium. The vegetative mycelium pressed the trunk epidermis from the inside until the trunk is damaged. Agrios (1996) stated that the important factor to resist a gall rust disease attack was the thickness and strength of the epidermis cells wall. Epidermis is the outer tissue of a young stem, which will be attacked first, and therefore, the thickness and strength of epidermis cells wall form barrier from attacks of any pathogens.

Gall rust disease also influenced tissue form. The susceptible individuals attacked by gall rust disease had irregular wood tissue with fused cell walls and contained hyphae of the infecting fungi (Figure 3.C).

Table 1. Different morphological characters of resistant and susceptible sengon tree trunks to gall rust disease

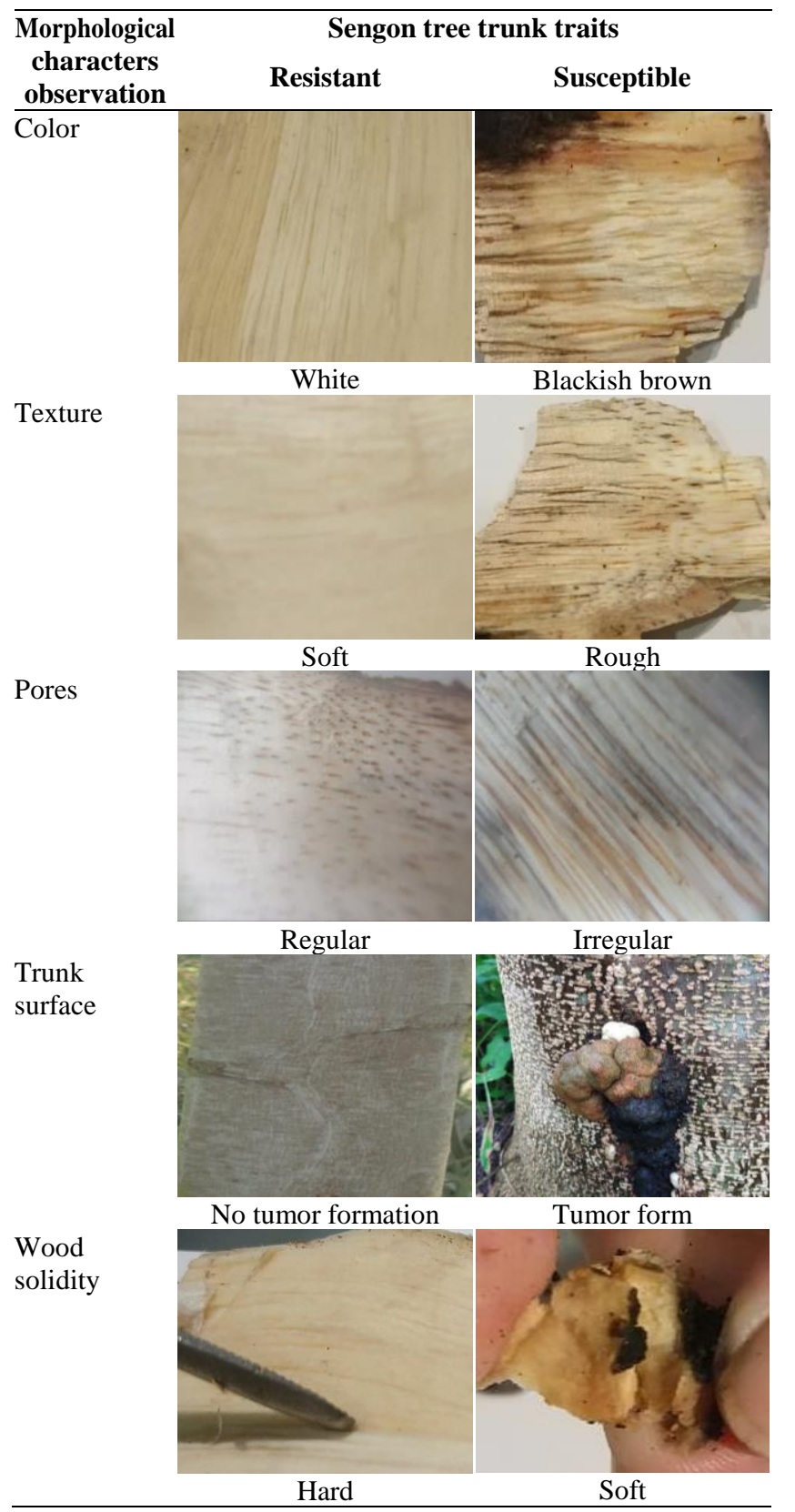




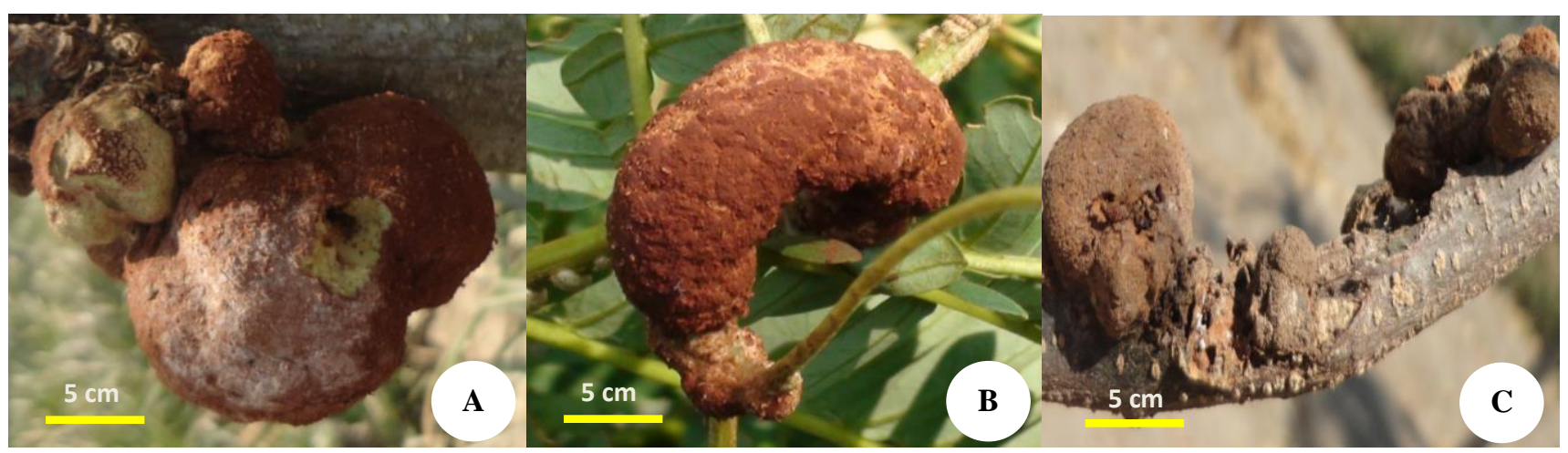

Figure 1. Morphological symptoms of gall rust disease attack on sengon tree: A. Initial active tumor having round shape and brownish green color; B. Active and dispersible spores having reddish brown color covering the tumor; C. Inactive spores indicated by blackcolored tumor

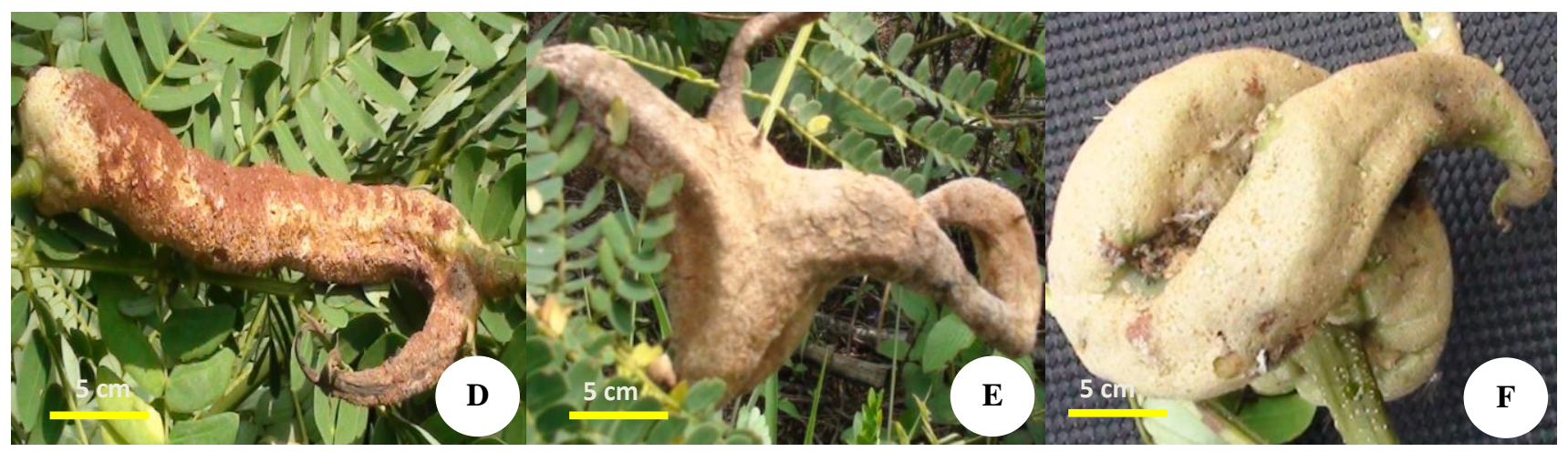

Figure 2. Variation of tumor shapes at tree. A. Tumor on the shoot tip; B. Tumor at the branches; C. Tumor at the young twigs

This indicated that there had been severe cell damage of wood tissue as a response of the host tree to the pathogen attack. Agrios (1996) mentioned that infected plant would fight the pathogen attack by changing its anatomical structure and increasing its cells size. Biruliova et al. (2013) stated that Uromyces geranii infection on Geranium (Geranium sanguineum L.) showed hypertrophic changes in tissues, in cortex form and in cortex cell size which became elongated with larger intercellular space. Larger cortex cell size caused fungal spore to be blocked to attack deeper tissue. The enlarging process of cells size might be caused by excessive auxin hormone produced by the infected plants.

Starch granules found in susceptible wood tissue indicated organelles degradation of wood cells, which were destroyed presumably by an enzyme produced by the infecting fungi (Figure 3.D). Fungi hyphae have the adaptability to penetrate, externally digest, absorb and metabolize various organic materials of wood. Mycelium of fungi will grow and disperse to every direction in the wood substrate and the hyphae produce enzymes that decompose the components of wood cell walls (Muin et al. 2000). Most fungi produce enzymes, which destroy cellulose or lignin of plant cells. Cellulose and lignin are the major components in the plant cell walls structure (Agrios 2005). Chitinase, 1.3-glucanase, and osmotin are proteins that are formed in response to a pathogen attack and are known to function as antifungal agents. Chitinase enzymes have the ability to degrade fungi cell walls, whereas osmotin is often formed when plants are under stress. It is estimated that osmotin causes a pore hole in the fungi cell plasma membrane. Plants are capable of producing two highly resistant chitinase and 1.3-glucanase enzymes against fungi infections (Hidayah and Suhara, 2005).

Observation of susceptible wood to gall rust disease can describe the invasion capability of $U$. falcataria penetrating its hyphae into the inner cells causing the damage of sengon trunk wood (Figure 3.E and F). Physically, the invasion of $U$. tepperianum was confirmed by the existence of the fungi hyphae that caused changes in cells size and shape. Pathogenic fungi causing gall rust disease produces a toxin, which attacks the overall tissues from cuticle up to vascular tissues (Agrios 1996). Infection on sengon tree was initiated by germination of active teliospores formed by U. falcataria, which are easily dispersed by the wind (Widyastuti et al. 2013). Fungi artificial inoculation on sengon leaves in laboratory condition explained the infection process of $U$. falcataria starting from direct penetration into the epidermis of host tree up to the penetration peg producing vesicles and hyphae inside plant tissues. The resistant sengon tree accession might have mechanisms to hamper the development and growth of pycnidia, a fruiting body, which is formed by fungi as a response to plant condition and environment. Teliospores of $U$. tepperianum could not directly infect the host tree. Rahayu et al. (2010) explained that teliospores have to go through germination process to become basidiospores which will infect the host tree by directly penetrate the epidermis or indirectly through stomata, epidermis cracks, and lenticels. 


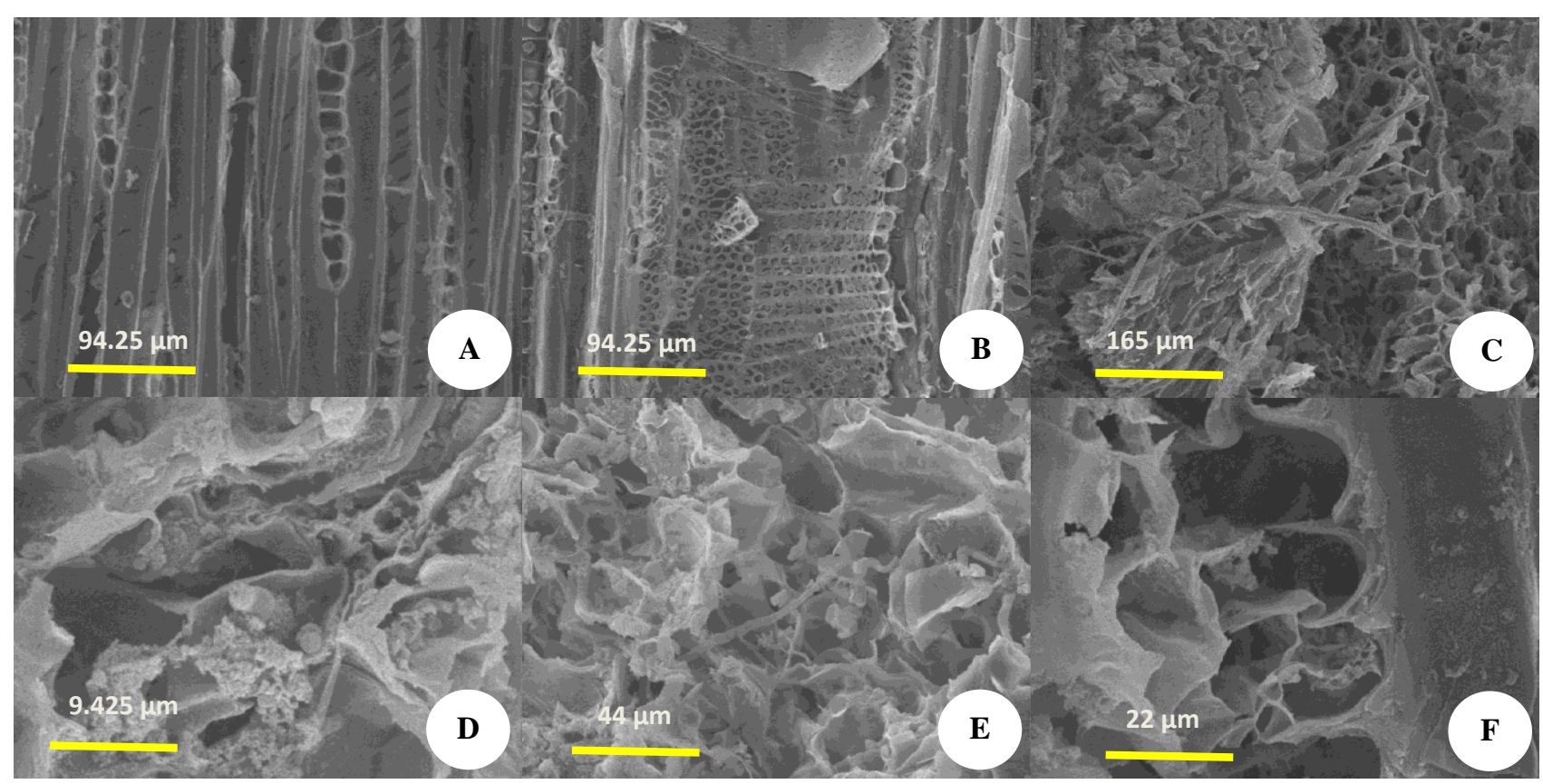

Figure 3. Three dimensional profile of sengon wood anatomy of resistant and susceptible individuals to gall rust disease; section radial longitudinal. A. resistant sengon wood tissue (from healthy and unattacked area of a wood) (x350); B. Resistant sengon wood tissue (x350); C. Susceptible sengon wood tissue: invasion of infecting fungi hyphae destroying wood tissue; D. Susceptible sengon wood tissue (from the attacked area of a wood): gall rust disease attacks starch granules in cell (x3500); E. Susceptible sengon wood tissue: formation of intracellular hyphae (x750); F. Susceptible sengon wood tissue: irregular form of sengon wood tissue due to gall rust disease attack (x1500).

Table 2. Phytochemical observation of secondary metabolites of resistant and susceptible sengon trunk to gall rust disease.

\begin{tabular}{lcc}
\hline \multirow{2}{*}{$\begin{array}{l}\text { Secondary metabolite } \\
\text { compound }\end{array}$} & \multicolumn{2}{c}{ Sengon tree trunk } \\
\cline { 2 - 3 } & Resistant & Susceptible \\
\hline Alkaloids & - & - \\
Flavonoids & +++ & ++ \\
Phenol Hydroquinones & ++ & +++ \\
Tannins & ++ & +++ \\
Saponins & ++++ & +++ \\
Triterpenoids & +++ & ++ \\
Steroids & ++++ & + \\
\hline
\end{tabular}

Notes: $(-)$ = negative; $(+)=$ positive but weak reaction; $(++)=$ positive and moderate reaction; $(+++)=$ positive and strong reaction; $(++++)=$ positive and very strong reaction.

\section{Qualitative secondary metabolite analysis}

Resistant sengon tree contained stronger inhibitor substances (or secondary metabolite compounds) than that of susceptible tree. Table 2 shows the biochemical reaction result was visually more intense on triterpenoids and steroids in the resistant sengon tree trunk. Triterpenoids and steroids contained in the sengon tree trunk is the biochemical resistance mechanism to fight fungi attack. These two substances are also antimicrobials (Doughari 2012). The main role of triterpenoids is disrupting cells membrane of fungi by forming complex with sterol in the fungi membrane (Ahmad et al. 2010). Steroids and triterpenoids are also active as antimicrobials in Avicennia marina (Windayu 2013).

Alkaloids were not detected in both resistant and susceptible sengon trees (Table 2), which means that alkaloids do not have the role in biochemical resistance of sengon tree against gall rust fungi. This result is in agreement with the study conducted by Fahrizal (2014) which found out that alkaloids were negative in the phytochemical analysis of sengon wood. Alkaloids may have been abundantly located in certain parts of the tree, but not in the trunk. Eleanore (2013) stated that alkaloid was found in sengon leaves, which made sengon leaves as the potential natural source for antioxidant. In general, alkaloids present in seed and fruit, such as avocado (Persea americana Mill.), (Marlinda et al. 2012). The alkaloids are a strong activator for immune cells to destroy bacteria, virus, fungi and cancer cells (Gholib 2009).

The trunk of sengon that was clear from gall rust attacks has more flavonoid and saponin content than those infected with gall rust. Saponins compound contained in the trunk of Ambon banana (Musa paradisiaca var. sapientum) can inhibit the growth of Candida albicans, which is shown by the existence of inhibition zone on filter paper used to test the potency of saponins against Candida albicans (Yuliana et al. 2016). This means that saponins have potency as antifungal by destroying fungi cell membrane resulting in cell leakage. The leakage causes the discharge of protein, nucleic acid, and nucleotide from fungi cells, which trigger the cells death. In plants, saponins have important role as antifungal, antibacterial, antivirus, antiprotozoal and causes metabolism interference in insects (Mert-Turk 2006). In the cell membranes, saponin interacts with sterol causing porous formation and therefore, decreasing membrane integrity. Flavonoids function as pigment and defense against pests and diseases. Flavonoids extracted from rain tree (Samanea saman (Jacq.) Merr) can inhibit the growth of pathogenic Fusarium sp. in dragon fruit (Sariningsih et al. 2015). Extract of Pycnoporus sanguineus contains flavonoids, carbolic acid and saponins, and it has antifungal capability towards Schizophyllum commune (Teoh and Don 2013).

The gall rust disease attack on susceptible sengon trees indicated the higher content of phenol hydroquinones and 
tannins compared to that on resistant sengon tree. Phenol hydroquinones and tannins were produced as a resistance response of sengon tree towards the gall rust disease attack. This is in agreement with observation carried out by Yanti (2015) on Anthocephalus spp. which has an increase in phenols and tannins contents due to Botryodiplodia theobromae infection. Polyphenol oxidase activity is higher in the resistant plant with minor infection compared to that in susceptible or healthy susceptible with some infection (Agrios 2005). Monoterpene of Citrus sinensis flower has a role as antifungal towards Colletotrichum acutatum which may be related to biochemical resistance (Marques et al 2014). Resistance reaction occurs due to the accumulation of high concentrations of phytoalexins which form the limiting area for pathogenic infection. The content of antimicrobial compound in the resistant plant is higher than that in the susceptible plant because the antimicrobial compound has a role as inhibitor for pathogen development in the plant (Hidayah and Suhara 2005).

In conclusion, the gall rust fungi caused changes of color, texture, pores, trunk surface, and decrease of wood solidity also damaged the wood tissue, which appeared as dispersed and irregularly structured wood anatomy. Hyphae of the infecting fungi were detected inside the susceptible sengon trunk. On the other hand, sengon tree, which is resistant to gall rust disease has organized and regularly structured wood anatomy without any penetrating hyphae. Phytochemical analysis showed that trunk of sengon contained flavonoids, saponins, phenolic hydroquinones, tannins, triterpenoids, and steroids, but did not contain alkaloids. The resistant individual to gall rust disease contained stronger reactions for flavonoids, saponins, triterpenoids, and steroids compared to the susceptible one.

\section{ACKNOWLEDGEMENTS}

This research is part of the thesis of the first author. The authors gratefully acknowledge the financial support from the SEAMEO BIOTROP DIPA Funding received by the third author. We gratefully acknowledge the funding from USAID through SHERA Program-Centre for Development of Sustainable Region (CDSR). We would like also to thank Dr. Noor Farikhah Haneda, Department of Silviculture, Faculty of Forestry, Bogor Agricultural University (IPB) for providing information and assistance on the sites of infected sengon plantation in Sukabumi.

\section{REFERENCES}

Achmad, Hadi S, Harran S, Sa'id EG, Satiawiharja B, Kardin MK. 2012. Attack mechanism of damping-off pathogens of Pinus merkusii. J Silva Trop 3 (1): 57-64. [Indonesian]

Agrios GN. 1996. Plant Diseases Science. Gadjah Mada University Press, Yogyakarta, Indonesia. [Indonesian]

Agrios GN. 2005. Plant Pathology. Elsevier, New York.

Ahmad I, Owais M, Shahid M, Aqil F. 2010. Combating Fungal Infections: Problems and Remedy. Springer-Verlag, Berlin.

Anggraeni I, Lelana NE. 2011. Gall Rust in Sengon. Badan Penelitian dan Pengembangan Kehutanan, Jakarta, Indonesia. [Indonesian]

Anggraeni I. 2009. Gall Rust Disease on Sengon (Paraserianthes falcataria (L) Nielsen) in Glenmore Plantation, Banyuwangi, East Java. J Penel Hut Tan 6 (5): 311-321. [Indonesian]

Biruliova E, Irina P, Alexandra F, 2013. The rust fungus uromyces geranii (D.C) Lev. localization and impact on anatomy of the host plant Geranium sanguineum L. Mod Phytomorphol 4: 109-113.
Darwiati W, Anggraeni I. 2018. The boktor (Xystrocera festiva Pascoe) and tumor (Uromycladium Tepperianum (Sacc.) Mcalpine) attack at sengon (Falcataria Mollucana (Miq.) in the plantation of Tea Ciater. J Sains Natural 8 (2): 59-69. [Indonesian]

Defianti KP, Mukarlina, Linda R. 2015. Anatomical structure of langsat stem (Lansium domesticum Corr.) attacked with stem cancer. Protobiont 4 (1): 62-68. [Indonesian]

Deka, Saikia. 2000. Chemical modification of wood with thermosetting resin: effect on dimensional stability and strength property. Bioresource 72 (2): 179-181.

Doughari JH. 2012. Phytochemicals: extraction methods, basic structures and mode of action as potential chemotherapeutic agents. Federal University of Technology P.M.B., South Africa. DOI: 10.5772/26052.

Doungsa-ard C, McTaggart AR, Geering ADW, Dalisay TU, Ray J, Shivas RG. 2015. Uromycladium falcatarium sp. nov., the cause of gall rust on Paraserianthes falcataria in south-east Asia. Austr Plant Pathol 44 (1): 25-30.

Eleanore Y. 2013. Phytochemical Analysis and Antioxidant Activity of Sengon (Falcataria moluccana (L) Nielsen) leaves extract used DPPH Method. [Indonesian] [Hon. Thesis]. Institut Pertanian Bogor, Bogor. [Indonesia]

Fahrizal Md. 2014. Total flavonoid, phenolic, and antioxidant activity of Paraserianthes falcataria (L.)) bark extract. [Hon. Thesis]. Institut Pertanian Bogor, Bogor. [Indonesian]

Gholib D. 2009. Inhibition potential of Melastoma malabathricum L. leaves against Trichophyton mentagrophytees and Candida albicans Berita Biologi 9 (5): 523-527. [Indonesian]

Harborne JB. 1984. Phytochemical Methods: A Guide to Modern Techniques of Plant Analysis. 2nd ed. Chapman \& Hall, London

Hidayah N, Suhara C. 2005. Evaluation of cotton accessions resistance to wilted disease by Fusarium. Proceeding of Workshop on Cotton Agribusiness Revitalization Integrated within Rainfed Paddy Field Land, September 8, 20015, Lamongan, Indonesia. [Indonesian]

Marlinda M, Sangia MS, Wuntua AD. 2012. Analysis of secondary metabolite compounds and toxicity test of ethanol extract of avocado seeds (Persea americana Mill.). J MIPA Unsrat Online 1 (1): 24-28. [Indonesian]

Marques JPR, Amorim L, Junior GJS, Spo MB, Sito, Gloria BA. 2014. Structural and biochemical characteristics of citrus flowers associated with defence against a fungal pathogen. AoBPLANTS 7: 1-10.

Mert-Turk F. 2006. Saponins versus plant fungal pathogens. J Cell Mol Biol 5: 13-17.

Muin M, Arif A, Syahidah. 2000. Deterioration and Improvement of Nature of Wood. Universitas Hasanudin, Makassar. [Indonesian]

Pandit IKN, Nandika D, Darmawan IW. 2011. Analysis of the nature of the timber of community plantation forest products. Jurnal Ilmu Pertanian Indonesia 16 (2): 119-124. [Indonesian]

Rahayu S, Lee S.S. 2008. Environmental conditions and gall rust disease development on in South East Asia, Case study in Sabah Malaysia and Java Indonesia. In: Asia and the Pacific Forest Health Workshop Forest health in a changing world. IUFROAPFISN. Kuala Lumpur, 13 December 2008

Rahayu S, Lee SS, Nor AS. 2010. Uromycaldium tepperianum, the gall rust fungus from Falcataria moluccana in Malaysia and Indonesia. J Mycos 51: 149-153

Rahayu S. 2010. Training on Gall Rust on Sengon and Its Management. Universitas Gadjah Mada, Yogyakarta. [Indonesian]

Sarinigsih P, Rita WS, Puspawati NM. 2015. Flavonoid compound identification and activity test of Tembesi Leaves extract (Samanea saman (Jacq.) Merr) as Fusarium sp. Fungi controller on dragon fruit plant. J Chem 9 (1): 20-26.

Teoh YP, Don MM. 2013. In vitro antifungal activities and phytochemical analysis of filamentous white-rot fungi, Schizophyllum commune. Sains Malaysiana 42 (9): 1267-1272.

Verpoorte R, Alfermann AW. 2000. Metabolic Engineering of Plant Secondary Metabolism. Springer, Berlin.

Widyastuti SM, Harjono, Zulchan AS. 2013. Initial infection of Falcataria moluccana leaves and Acacia mangium phyllodes by Uromycladium tepperianum fungi in a laboratory trial. J Trop For Manag 19 (3 ): 187-193.

Windayu ME. 2013. Antimicrobial Activity from Avicennia marina Against Bacteria and Fungi Pathogenic by In Vitro. [Hon. Thesis]. Institut Pertanian Bogor, Bogor. [Indonesian]

Wiryadiputra S. 2017. Tumor Disease Epidemic in Sengon (Paraserianthes falcataria) in East Java, Indonesia. [Indonesian]

Yanti LA. 2015. Resistance of White and Red Jabon Seeds (Anthocephalus spp.) To Attack of Botryodiplodia theobromae Caused by Tropical Dead Disease. [Thesis]. Institut Pertanian Bogor, Bogor. [Indonesian]

Yuliana SR, Leman MA, Anindita PS. 2016. The test of inhibitory of stem banana (Musa Paradisiaca) saponin compound against the growth of Candida albicans. Jurnal eGigi 3 (2): 616-620. [Indonesian] 


\section{BIODIVERSITAS}

ISSN: 1412-033X

Volume 20, Number 3, March 2019

E-ISSN: 2085-4722

Pages: 907-913 